\title{
Californiens \\ Gegenwart und Zukunft
}

von

J. Hoppe.

\section{Nebst Beitrãgen \\ von}

A. Erman

Ueber die Klimatologie von Californien

and

Ueber die geographische Verbreitung des Goldes.

Hierzu zwei Karten: 1) Californien von J. Hoppe. 2) Die bis 1849 bekannt gewordenen Golddistrikte von A. Erman.

$$
\begin{gathered}
\text { B e r l i n, } \\
\text { Verlag von G. Reimer. }
\end{gathered}
$$

1849. 
